\title{
The protection of stakeholders: The South African social and ethics committee and the United Kingdom's enlightened shareholder value approach: Part 1
}

\author{
Irene-Marié Esser \\ $L L M L L D$ \\ Senior Lecturer in Commercial law, University of Glasgow; Professor \\ Extraordinarius, University of South Africa; Visiting Professor, The Open University, \\ United Kingdom
}

Piet Delport

LLD H DipTax Law

Professor of Mercantile Law, University of Pretoria

\begin{abstract}
OPSOMMING
Die beskerming van belanghebbendes: die Suid-Afrikaanse maatskaplike- en etiekkomitee en die Verenigde Koninkryk se verligte aandeelhouersbelang benadering: Deel 1
\end{abstract}

Maatskappyereg is nog altyd baseer op die beginsel dat die direksie die maatskappy moet bestuur in die beste belang van die maatskappy. "Maatskappy" in hierdie sin beteken die maatskappy as afsonderlike regsentiteit, met verwysing na die vermoënsmaksimalisering van die belange van die aandeelhouers. Die belange van die ander belangehouers, soos die werknemers, staat en verbruikers kon in ag geneem word, maar die fokus is die aandeelhouers se belange. Hierdie teorie van die uitgebreide aandeelhouersbelang ("enlightened shareholder approach") is ook aanvaar as die basis van die Suid-Afrikaanse Maatskappywet 71 van 2008, in stede van die meervoudige belange benadering ("pluralist approach"). Daar is egter 'n duidelike verandering ten opsigte van die voortgesette absolute toepassing van eersgenoemde benadering te bespeur, nie net in die Suid-Afrikaanse konteks nie, maar ook wêreldwyd. Hierdie beweging is miskien begin deur instrumente soos Kodes, maar in die Suid-Afrikaanse Maatskappywet is daar ook nou spesifieke bepalings wat aan sekere belangegroepe direkte remedies verleen. Daar is twee modelle wat die direksie in staat stel om hierdie ander belange in ag te neem, en in Suid-Afrika geskied dit deur die Sosiale en Etiese Komitee, terwyl dit in die Verenigde Koningkryk gedoen word deur middel van 'n spesifieke statutêre bepaling, alhoewel laasgenoemde nie direk afdwingbaar is deur die belangegroepe nie. In hierdie artikel word die twee modelle in oënskou geneem en die effektiwiteit daarvan word ge-evalueer, veral in die lig van die praktiese probleme en die wenslikheid van sulke inisiatiewe, sonder dat die basiese gemeneregreël ten opsigte van die aandeelhouerfokus uitdruklik gewysig word. 


\section{Introduction}

A basic element of the duties of directors is that directors must act in the interest of the company. The company in this sense was always interpreted as the 'metaphysical entity', and this translated into the interest of all the members, present and future, and, in certain instances, such as when the company is insolvent, also the creditors. "[T]he interests of the consumers of the company's products, the nation as a whole and even... the employees are legally irrelevant." ${ }^{1}$ This philosophy changed and, in South Africa at least, it was initially led by codes. The self-regulatory South African King III Report on Corporate Governance ${ }^{2}$ specifically addresses corporate social responsibility (CSR) and opted for the so-called inclusive stakeholder value approach. ${ }^{3}$ This implies that the board should consider the interests of all legitimate stakeholders, like

1 Gower, Cronin, Easson and Lord Wedderburn of Charlton Gower's Principles of Modern Company Law, Stevens \& Sons (1979) 577 and authorities cited. See also Lombard Directors' Duties to Creditors (LLD Thesis 2006 University of Pretoria). See further Hodes 'The social responsibility of a company' 1983 SALJ 468 in respect of the initial basis of corporate social responsibility.

2 The King Code of Governance for South Africa 2009 (the Code) and the King Report of Governance in South Africa 2009 (hereafter King III). The Institute of Directors in Southern Africa (the IoDSA) also issues Practice Notes on King III. The King II Report on Corporate Governance of 2002, replacing King $I$, was applicable to South African enterprises until the end of February 2010 after which King III became effective. The Code is available at: www.iodsa.co.za. Copyright of the Code and the Report rests with the Institute of Directors in Southern Africa. The Report is also available at www.iodsa.co.za. On King II, see: Loubser 'Does the King II Report solve anything?' 2002 Juta's Business Law 135. For a detailed discussion of King III see: Loubser 'The King Reports on corporate governance' in Esser and Havenga (eds) Corporate Governance Annual Review 20122012 20ff. King IV was launched on 1 November 2016 (http://www.iodsa.co.za/page/ KingIVReport.) Disclosure on the application of King IV is effective in respect of financial years starting on or after 1 April 2017 but immediate transition is encouraged. King IV replaces King III in its entirety. King IV operates in terms of practices, principles and governance outcomes. The practices will support the principles and this will lead to the governance outcomes. King $I V$ is, similar to its predecessors, a set of voluntary principles and practices. Some of these practices have been legislated being in line with international hybrid systems of good governance. The main objective with King IV was to make it as accessible and fit to as many organisations as possible. In view of this King IV is based on an 'apply and explain' approach of disclosure. As all principles are phrased as aspirations and ideals that organisations should strive to achieve to give effect to the governance outcomes, application of the principles is assumed. The explanation that is given will be a high level disclosure of the practices that have been implemented and the progress that has been made in the journey towards giving effect to each principle.

3 See par 9 of the Introduction and Background part in the King III Code as well as 8 in the Report. This is still the case in King IV (see page 25 where a stakeholder-inclusive approach is recommended). 
employees and creditors, and not just those of the shareholders. ${ }^{4}$ The various interests of different stakeholders should be determined on a case-by-case basis, and the decision to act in the best interests of the company and a particular stakeholder may well, in a particular situation, receive preferential treatment, provided it serves the ultimate interests of the company best. This self-regulatory approach was complimented with some legislative provisions and stakeholders in general are now, at least indirectly, protected in the 2008 South African Companies Act. ${ }^{5}$ Various provisions of the 2008 Companies Act provide stakeholders with some form of protection, ${ }^{6}$ while particular classes of stakeholders, such as employees, are afforded specific protection measures. ${ }^{7}$ A critical analysis of these provisions is not within the scope of this article and our aim is to focus on the new procedural requirement of a social and ethics committee in respect of certain companies and the protection that it offers stakeholders in general. A detailed analysis and appraisal will be provided, focusing on the appointment and functions of this committee, the practical relevance and, specifically, the effect that it will have on the shareholders. Regulation 43, under the Companies Act, ${ }^{8}$ deals with the social and ethics committee as referred to in section 72 of the Act.

A comparison will be made with the position in the United Kingdom. ${ }^{9}$ Both South Africa and the United Kingdom make use of a hybrid system

4 Section 1 of the Companies Act 71 of 2008 ('2008 Companies Act') defines a 'shareholder' as the holder of a share issued by the company and whose name is entered as such in the (certificated or uncertificated) securities register. The 'holder' of shares (without it being entered as such in the (certificated or uncertificated) securities register) or of voting rights or other 'beneficial interest' is used in different contexts throughout the Act. A 'holder of shares' and a 'shareholder' are therefore, for purposes of the Act, not synonyms. See Delport (ed) Henochsberg on the Companies Act 71 of 2008 (Service issue April 2016) (hereafter Henochsberg) 30(1). The extended definition of a shareholder as in s 57 of the 2008 Companies Act which in essence includes the beneficial shareholder, only applies to Part F of Chapter 2, i.e. in respect of the governance of companies.

5 See also Minister of Water Affairs and Forestry $v$ Stilfontein Gold Mining Co Ltd 20065 SA 333 (W) where it seems if the courts are holding directors liable if they do not comply with King (in this case, King II) stating that that in itself can result in a breach of the duty to act with care, skill and diligence.

6 This is discussed in detail in Esser 'Corporate social responsibility: a company law perspective’ 2011 SA MercLJ 317.

7 See for examples para 3 infra.

8 GN R 351 of 26 April 2011 in terms of s 223 of the Companies Act ('Regulations'). The Regulations are subordinate legislation and the power to make the regulations is restricted by the particular enabling provision in the Act. As subordinate legislation it cannot amend the Act or be used to interpret the enabling Act: See in general about subordinate legislation Executive Council, Western Cape $v$ Minister for Provincial Affairs and Constitutional Development and Another; Executive Council, KwaZulu-Natal v President of the Republic of South Africa 20001 SA 661 (CC).

9 See De Jure 17(2) for part 2 of this article. 
of corporate governance, where rules and principles are embedded in legislation, as well as self-regulatory codes. ${ }^{10}$ Despite this, the approach with regard to the protection of the interests of stakeholders has been dealt with differently in South Africa and the United Kingdom.

The United Kingdom has opted to alter the best interest duty of directors legislatively to include the interests of stakeholders when acting to promote the success of the company. ${ }^{11}$ South Africa has instead placed the monitoring of stakeholder interests within the ambit of the above-mentioned committee, whose task is to report to the shareholders and draw the attention of certain matters, within its mandate, to the board.

The different approaches, i.e. of process versus rules, of the United Kingdom and South Africa respectively will be compared to indicate the preferred one. This article is divided into two parts. ${ }^{12}$ Part 1 provides the theoretical background on the nature of the company and the stakeholder debates in South Africa and the United Kingdom. In Part 2 we discuss the practical application of the stakeholder concepts in South Africa and in the United Kingdom and reach certain conclusions and form a view on whether or not the South African procedural approach of a social and ethics committee or the United Kingdom's rule approach of a codified duty best protects the interests of stakeholders.

\section{The Nature of the Company}

In South Africa and the United Kingdom, at common law, directors have to act honestly in the best interests of the company. This has always been interpreted as the shareholders collectively, both present and future. ${ }^{13}$

10 This article will not evaluate the advantages and disadvantages of selfregulation versus legislation. As mentioned the focus is on the protection of the interests of stakeholders. On self-regulation versus legislation, see generally: DeJong A, DeJong DV, Mertensa and Wasley 'The role of selfregulation in corporate governance: evidence and implications from the Netherlands' 2005 Journal of Corporate Finance 473-503; Graham and Woods 'Making corporate self-regulation effective in developing countries' 2006 World Development 868-883; Demaki 'Proliferation of codes of corporate governance in Nigeria and economic development' 2013 Business and Management Review 37-42.

11 See, generally, Wilkinson Will Social and Ethics Committees Enlighten Shareholders? A Comparison of the South African provisions relating to Social and Ethics Committees with the Enlightened Shareholder Value Approach in the United Kingdom Companies Act 2006 (LLM Dissertation 2011 University of Johannesburg).

12 See De Jure 17(2) for part 2 of this article.

13 See Hutton $v$ West Cork Railway Company (1883) LR 23 ChD 654, 673 and the well-known quotation that: 'The law does not say that there are to be cakes and ale, but there are to be no cakes and ale except such as required for the benefit of the company.' According to Re Smith \& Fawcett [1942] Ch 304, 306 directors were supposed to 'exercise their discretion bona fide in what they consider - not what a court may consider - is in the interests 
During the company law reform processes of both South Africa and the United Kingdom the issue as to whom directors owe their duties was debated in detail. ${ }^{14}$ There are, generally, two schools of thought on the issue of whose interests must be granted primacy when directors manage companies. In the enlightened-shareholder-value approach, the primary role of the directors should be to promote the success of the company for the benefit of the shareholders as a whole and to generate maximum value for shareholders. The second school is that of plurism, which sees shareholders as one constituency among many and the interests of a number of groups are recognised. Thus, a company's existence and success are seen as inextricably intertwined with the consideration of the interests of its employees and other potentially

of the company, and not for any collateral purpose.' See the discussion in Kershaw Company Law in Context (2012) $331 \mathrm{ff}$. See also Percival $v$ Wright [1902] 2 Ch 421 and Peskin v Anderson [2000] All ER (D) 2278. See Dawson International Plc $v$ Coats Paton Plc [1989] BCLC 233 where a distinction was drawn between the 'interests of the company' and the 'interests' of 'current shareholders'. See also Brady v Brady [1988] BCLC 20 on the interests of the company, as an artificial person, being those of the shareholders both present and future. Observance of this duty entails only the honest exercise by the directors of their judgment as to what is in the company's interests (In re Smith \& Fawcett Ltd supra 306). The Court is not concerned to enquire into the commercial or financial wisdom of the directors' decisions (Levin $v$ Felt \& Tweeds Ltd 1951 (2) SA 401 (A) 414-415; Howard Smith Ltd v Ampol Petroleum Ltd [1974] 1 All ER 1126 (PC) 1131). But in deciding whether the duty has been observed the Court may properly consider whether in the circumstances a reasonable man could have believed that the particular act was in the interests of the company (Charterbridge Corporation Ltd $v$ Lloyds Bank Ltd [1970] Ch 6274 (obiter); [1969] 2 All ER 1185 1194; Visser Sitrus (Pty) Ltd v Goede Hoop Sitrus (Pty) Ltd 20145 SA 179 (WCC) para 74; Howard Smith supra 1133; and see the Canadian case of Teck Corporation Ltd $v$ Millar 197333 DLR (3d) 288 315-316 where Berger J stated: 'I think the Courts should apply the general rule in this way: The directors must act in good faith. Then there must be reasonable grounds for their belief. If they say that they believe there will be substantial damage to the company's interests, then there must be reasonable grounds for that belief. If there are not, that will justify a finding that the directors were actuated by an improper purpose.' $C f$, in a different context, Shuttleworth $v$ Cox Brothers \& Co (Maiden head) Ltd [1927] 2 KB 9 (CA) 23. This is discussed in detail in Henochsberg 295.

14 See on the company law reform processes in South Africa: The Policy document of the Department of Trade and Industry. The guidelines for corporate law reform, South African company law reform for a 21st Century (GG 26493 of 23 June 2004, hereafter the Policy document) and in the United Kingdom: The CLRSG, Modern Company Law for a Competitive Economy: The Strategic Framework (DTI February 1999) (the Strategic Framework); CLRSG, Modern Company Law for a Competitive Economy: Developing the Framework (DTI March 2000) (Developing the Framework); CLRSG, Modern Company Law for a Competitive Economy: Completing the Structure (DTI November 2000) (Completing the Structure); CLRSG, Modern Company Law for a Competitive Economy: The Final Report (Vols I and II, DTI 2001) (Final Report) White Paper, Company Law Reform (March 2005) Cm 6456 (the White Paper). On the UK reform process, see: Rickford 'A history of the company law review' in De Lacy (ed) The Reform of United Kingdom Company Law (2002) 3-37 and Goddard 'Modernising company law: the government's white paper' 2003 Modern Law Review 402-424. 
qualifying stakeholders in the business, such as suppliers and customers. ${ }^{15}$

The protection that has to be afforded to stakeholders has been widely debated in South Africa. ${ }^{16}$ The Policy document, issued prior to the commencement of the company law reform process which commenced in 2004, referred to it as an important issue that the drafters of the new Companies Act had to consider. The King reports emphasise CSR principles and that companies must act as responsible corporate citizens. The common law position that a director has to act bona fide in the best interests of the company is now entrenched in the Act. ${ }^{17}$ The common law will still be applicable, as long as it does not conflict with the current Act. Even though the common law position is still applicable, and now

15 As to corporate social responsibility in the context of directors' duties see, inter alia, Olson 'South Africa moves to a global model of corporate governance but with important national variations' 2010 Acta Juridica 219. 247; Esser 2011 SA MercLJ 317-335; Stoop 'Towards greener companies sustainability and the social and ethics committee' 2013 Stell LR 562-582; Kloppers 'Driving corporate social responsibility (CSR) through the Companies Act: an overview of the role of the social and ethics committee' 2013 PER 165-199; Esser 'Shareholder interests and good corporate governance in South Africa' 2014 THRHR 38-52 and for a critical evaluation of the concept also Welling 'Corporate social responsibility - a wellmeaning but unworkable concept' 2009 Corporate Governance e-Journal, Bond University. On the various theories see: Coase 'The nature of the firm' 1937 Economica 386; Alchain and Demsetz 'Production, information costs, and economic organization' 1972 American Economic Review 777; Jensen and Meckling 'The theory of the firm: managerial behavior, agency costs and ownership structure' 1976 J of Financial Economics 305-360; Wishart 'Models and theories of directors' duties to creditors' 1991 New Zealand Universities LR 323; Dine 'Company law developments in the European Union and the United Kingdom: confronting diversity' 1998 TSAR 245. See further Garcia et al 'Shareholder vs. stakeholder: two approaches to corporate governance' 2008 Business Ethics, A European Review 1-7 and Mason and Simmons 'Embedding corporate social responsibility in corporate governance: a stakeholder systems approach' 2013 Journal of Business Ethics 1-10.

16 See Muswaka 'Shareholder value versus stakeholders' interests - a critical analysis of corporate governance from a South African perspective' 2015 Journal of Social Sciences 217-225 where it is argued that 'Traditionally, corporate governance focuses on the regulation of the directors' duties for the maximum welfare of the shareholders. As a result, stakeholder interests have held very little relevance under classical company law. However, the argument for imposing wider accountability on companies has gained importance and the issue of protecting stakeholders' interests has thus become crucial. Given this background, this paper examines the issue of the protection of stakeholders' interests under the Companies Act 71 of 2008. The main concern is whether the Companies Act adequately protects the interests of stakeholders. The paper concludes that even though efforts have been made in the Companies Act to ensure that other stakeholders, apart from just shareholders are protected, it seems that legislation is far from effectively providing for the rights of stakeholders. In this regard, recommendations for law reform are made.' See also Esser and Delport 'Shareholder protection philosophy in terms of the Companies Act 71 of 2008' 2016 Journal of Contemporary Roman Dutch Law 1-29.

17 See ss 76(3)(a) and (b) of the 2008 Companies Act. 
part of company legislation, the Companies Act brought some substantial changes to directors' duties and to whom they owe these duties. This is discussed below.

In the United Kingdom directors' duties were fully codified in the 2006 Companies Act. ${ }^{18}$ Section 172 replaced the common law duty to act in good faith in the best interests of the company. ${ }^{19}$ The duty now placed on directors is to promote the success of the company, but not as a separate legal entity, but rather for the benefit of the shareholders collectively. This section is, therefore, still in line with shareholder primacy. ${ }^{20}$ This section and the practical implications of it are discussed in detail later in this article. ${ }^{21}$

The nature of the company and the ultimate beneficiary of directors' duties determine the extent to which directors can consider the interests of other stakeholders and ultimately how far they can go to act corporate socially responsible, but still within their fiduciary duties. ${ }^{22}$ With this in mind, we will consider the protection afforded to stakeholders, focusing on the social and ethics committee in South Africa and the codified duty of directors to promote the success of the company having regard to various matters in the United Kingdom.

18 See ss $171-177$ of the 2006 Companies Act.

19 See also Keay 'Tackling the issue of the corporate objective: an analysis of the United Kingdom's 'enlightened shareholder value approach' 2007 Sydney Law Review 577-612; Fisher 'The enlightened shareholder - leaving stakeholders in the dark: will section 172 (1) of the Companies Act 2006 make directors consider the impact of their decisions on third parties' 2009 ICCLR 10 and Keay 'Shareholder primacy in corporate law: can it survive? Should it survive?' 2010 ECFR 369.

20 See Copp 'S.172 of the Companies Act 2006 fails people and planet?' 2010 CoLaw 406 where it is held that '... S.172 has raised expectations that it cannot deliver and would be better replaced with a traditional statement of a director's fiduciary duty of loyalty'. See Kong Shan Ho 'Is section 172 of the Companies Act 2006 the guidance for CSR?' 2010 Company Lawyer where it is stated that: 'Arguably s.172 does not in reality change directors' practice substantively. Indeed, the CLRSG during the consultation process thought that it simply reflected existing law and best practice.' and then concluded that section 172 enshrines 'the concept of the enlightened shareholder value approach and some of the potential implications which s.172 may have on corporate governance. Our starting point was whether company law can provide a solution to companies that want to integrate CSR into their long-term development strategies. The biggest problem with CSR is that it seems to be an altruistic utopia which is distant from the practical business world. Yet a provision like s.172 at least provides some guidance for businesses faced with the task of balancing different competing interests. So long as management can justify why they have come to a particular decision based on those statutory criteria, then there is no reason why they cannot claim they have integrated social and environmental concerns in their operations.

21 See part 2 of this article in De Jure 17(2) at para 6.2.1. See also Kershaw 382-385 for a concise summary of s 172 .

22 See McBarnet, Voiculescu and Campbell The New Corporate Accountability: Corporate Social Responsibility and the Law (2009) on CSR against the law. 


\section{Background: CSR in South African Company Law $^{23}$}

As stated above, the generally accepted view has traditionally been that companies are managed primarily in the interests of their shareholders collectively. Thus the duty of directors, to act in the best interest of the company, is to maximise profits for the shareholders. Over time, there has been a shift in public opinion towards the recognition of a variety of other interests that should be considered by company management. These include environmental concerns and the interests of other stakeholders like investors, employees, consumers and the general public.

King $I I^{24}$ became effective on 1 March 2010 and provides general principles regarding ethical leadership and corporate governance (Chapter 1) as well as principles of good governance relating to the board and directors (Chapter 2), audit committees (Chapter 3), the governance of risk and information technology (Chapter 4 and 5), compliance with laws, regulations, standards and rules (Chapter 6), internal audit (Chapter 7 ), governing stakeholder relationships (Chapter 8) and integrated reporting and disclosure (Chapter 9).

King III applies to all entities regardless of the manner and form of incorporation or establishment and whether in the public, private or nonprofit sectors. $^{25}$ The Institute of Directors also issued 'Regulations' that provide guidelines on how to implement the King Code, issued with the King III Report. King III operates on an 'apply or explain' basis. This is somewhat different from the 'comply and explain' basis that King II operated on as 'apply' gives less of an indication of prescriptiveness and the King III committee found the word 'apply' therefore more appropriate than 'comply'. 26

23 See Esser 2011 SA MercLJ 317 for the CSR legal framework in South Africa.

24 The King reports are issued under the auspices of the Institute of Directors of South Africa ('IoDSA'). The King III Report and the Code together are referred to as King III, although it is two separate documents.

25 See par 13 of the Introduction and Background part in the King III Code.

26 It is stated on the website of the IoDSA (iodsa.co.za accessed 2016-05-27) that: 'Like its 56 commonwealth peers, King III has been written in accordance to the 'comply or explain' principle based approach of governance, but specifically the 'apply or explain' regime. This regime is currently unique in the Netherlands and now in South Africa. Whilst this approach remains a hotly debated issue globally, the King III Committee continues to believe it should be a non-legislative code on principles and practices'. See also par 3 of the Introduction and Background part in the King III Code. 
King III once again opted for the inclusive stakeholder value approach $^{27}$ and indicates that, because a company is so integral to society, it should be considered as much a citizen of a country as any natural person. A company must therefore act as a responsible citizen. This involves that companies must follow the triple-bottom line approach by considering, social, environmental and economic factors when managing a company. ${ }^{28}$ In terms of the inclusive approach, directors must thus consider the interests of various stakeholders on a case-bycase basis. In the end, the decision must be in the best interests of the company, even if that particular decision may, in the short-term at least, be to the detriment of the shareholders. ${ }^{29}$

The King III Report pays specific attention to CSR issues in Chapter 1 dealing with ethical leadership and corporate citizenship, in Chapter 8 that deals with stakeholder relationships and Chapter 9, dealing with integrated reporting and disclosure. ${ }^{30}$ Many of the recommendations of King III are now embedded in the Companies Act, ${ }^{31}$ which could have the effect that some may be directly enforceable, while others not so contained in the Companies Act may lead to liability, even if not directly enforceable.

27 See par 9 of the Introduction and Background part in the King III Code as well as Chapter 8 of the Report. See on stakeholder protection in terms of the King III Report and for a comparison between King II and King III: Esser and Du Plessis 'The stakeholder debate and directors' fiduciary duties' 2007 SA MercLJ 346; Esser Recognition of Various Stakeholder Interests in Company Management (LLD Thesis 2008 Unisa) and Esser 'The protection of stakeholder interests in terms of the South African King III report on corporate governance: an improvement to King II?' 2009 SA MercLJ 188.

28 See p 12 of the King III Report and see Principle 1.2 of the King III Report.

29 See e.g. Swart v Beagles Run Investments 25 (Pty) Ltd 20115 SA 422 (GNP); African Banking Corporation of Botswana Ltd $v$ Kariba Furniture Manufacturers (Pty) Ltd 20155 SA 192 (SCA); Absa Bank Limited v Caine NO and Another, In Re; Absa Bank Limited v Caine (3813/2013, 3915/2013) [2014] ZAFSHC 46 (2 April 2014); Shoprite Checkers (Pty) Ltd v Berryplum 47327/2014 [2015] ZAGPPHC (9 March 2015); Panamo Properties (Pty) Ltd and Another v Nel 20155 SA 63 (SCA); Richter v Absa Bank Ltd 20155 SA 57 (SCA) para 13 on how the court balances the interests of shareholders and creditors in the context of the new business rescue proceedings. Employees also receive extensive protection in the 2008 Companies Act. See Katz 'Governance under the Companies Act 71 of 2008: flexibility is the keyword' 2010 Acta Juridica 248 261-262 where it is stated that employees receive, for the first time, significant rights of participation in the governance of companies. See, for example, ss 20(4), 45(5), 162(2), and 159 of the 2008 Companies Act. Employees also have extensive rights during business rescue proceedings. See in general also Davis and Le Roux 'Changing the role of the corporation: a journey away from adversarialism' 2012 Acta Juridica 306-325.

30 Integrated sustainability performance and integrated reporting are recommended in King III to enable stakeholders to make informed assessments on the economic value of a company. See par 9 of the Introduction and Background part in the King III Code as well as Chapter 9 of the Report.

31 See King 'The synergies and interaction between King III and the Companies Act 71 of 2008' in Mongalo (ed) Modern Company Law for a Competitive South African Economy (2010) 446 - 455; Loubser (2012) $20 \mathrm{ff}$. 
As stated before King IV was recently launched and will be effective in respect of financial years starting on, or after, 1 April 2017. The stakeholder-inclusive approach is once again preferred. ${ }^{32}$ Part 5.5. deals with stakeholder relationships. Principle 16 provides that 'In the execution of its governance role and responsibilities, the governing body should adopt a stakeholder-inclusive approach that balances the needs, interests and expectations of material stakeholders in the best interests of the organisation over time'. The stakeholder approach advocated by King IV is that:

[D]irectors owe their fiduciary duties to the company and to the company alone as the company is a separate legal entity from the moment it is registered until it is deregistered ... The company is represented by several interests and these include the interests of shareholders, employees, consumers, the community and the environment. Thus, requiring of directors to act in good faith in the interest of 'the company' cannot nowadays mean anything other than a blend of all these interests, but first and foremost they must act in the best interest of the company as a separate legal entity ... An interest that may be primary at one particular point of time in the company's existence, may well become secondary at a later stage. ${ }^{33}$

In a recent South African case, the court referred to a previous King Report by testing directors' conduct against the requirements in that Report. ${ }^{34}$ This may have far-reaching consequences, not just for directors of listed companies, as King III is now, in contrast to previous King Reports, applicable to all companies. The court found that by not complying with the principles embedded in King, directors may be in breach of their duty of care and skill. Directors' duties are now (nonexhaustively) codified in the Companies $\mathrm{Act}^{35}$ and this, coupled with a new liability provision in section $218(2)$ which provides: 'any person who contravenes any provision of the Companies Act is liable to any other person for any loss or damage suffered by that person as a result of that contravention', could have the effect that liability for breach of duties, also the duty of care and skill, can be extended to third parties, such as outside stakeholders. ${ }^{36}$ Although no direct rights are given to stakeholders, third parties still have some recourse available. First, any third party has the option of using section 218(2). Third parties can therefore argue that directors did not act in the best interests of the company, thus not as directed in section 76(3)(b) of the Companies Act, by not considering their specific interests. This will, however, be difficult

32 See King $I V$, page 25.

33 This approach is taken from: Esser and Du Plessis 2007 SA MercLJ 346. Reference is also made to Esser and Delport 2016 Journal of Contemporary Roman Dutch Law 1-29.

34 Minister of Water Affairs and Forestry $v$ Stilfontein Gold Mining Co Ltd supra. See on this case: Luiz and Taljaard 'Mass resignation of the board and social responsibility of the Company: Minister of Water Affairs and Forestry $v$ Stilfontein Gold Mining Co Ltd' 2009 SA MercLJ 420 and Esser and Delport 2011 Journal of Contemporary Roman Dutch Law 449.

35 See for example section 76(3)(b) that requires directors to act in the best interests of the company. As to the ambit of this duty see Henochsberg 295. Section 218(2) of the Companies Act, 2008. 
to prove as the third party will have to show that by not acting in his or her best interest the director did not act in the best interest of the company. Section 218(2) is drafted in very wide terms and this type of provision may prevent experienced people from serving as directors, although it may be difficult for third parties to succeed with a claim based on section 218(2). Third parties may also have some of the general remedy provisions of the Companies Act at their disposal. ${ }^{37}$ Directors may therefore be held accountable under the 2008 Companies Act for not complying with King. This does not make the duties legally enforceable, but non-compliance could lead to liability. ${ }^{38}$

In addition to the protection afforded to stakeholders in King III (and now King $I V$ ), stakeholders and the protection offered to them have more prominence in the Companies Act than in any previous company legislation in South Africa and is, at least indirectly, expressly recognised. As stated before, our focus is on the social and ethics committee as provided for in section 72(4). Several other sections afford protection to stakeholders too, especially section $218(2)$ referred to before. ${ }^{39}$ Section $7(d)$ also confirms that one of the purposes of the Act is to reaffirm the concept of the company as a means of achieving economic and social benefit. ${ }^{40}$

Section 76(3)(a) and (b) of the Companies Act provide as follows:

37 See Ch 7 of the 2008 Companies Act on remedies.

38 See Esser and Delport 2011 Journal of Contemporary Roman Dutch Law 449. Based on the Stilfontein decision supra it seems that if King is not complied with it will be taken into account when determining whether a director acted with the necessary care and skill. See Joubert 'Reigniting the corporate conscience: reflections on some aspects of social and ethics committees of companies listed on the Johannesburg Stock Exchange' in: Visser and Pretorius (eds) Essays in Honour of Frans Malan (2014) 183-195 187 where he states that: '.. the fact that conforming to the code is taken into account by the courts when they determine whether directors have acted bona fide in the interest of the company is not authority for the proposition that the code has become legally enforceable ...'

39 See Esser 2011 SA MercLJ $317 \mathrm{ff}$ for a detailed discussion of the CSR provisions in the 2008 Companies Act. However, the exact ambit of s 218(2) is uncertain, and especially whether it offers a remedy in addition to other remedies (e.g. for a shareholder who has certain personal common law and statutory remedies) or only in the circumstances if there are no other remedies. See Henochsberg 639; Austin, Ramsay Ford's Principles of Corporations Law (2013) para 8.360; Phoenix Constructions Queensland Pty Ltd v Coastline Constructions Pty Ltd and McCracken [2011] QSC 167: reversed on appeal in Phoenix Constructions (Qld) Pty Ltd $v$ McCracken [2012] QCA 129; Lombard and Joubert 'The legislative response to the shareholders v stakeholders debate: a comparative overview' 2014 Journal of Corporate Law Studies 211-240.

40 See Jennings 'Are shareholders exclusive beneficiaries of fiduciary duties in South Africa? The role of fiduciary obligations in the 21 st Century' 2015 The Journal of Corporate and Commercial Law \& Practice 54-81. 
A director of a company, when acting in that capacity, must exercise the powers and perform the functions of director (a) in good faith and for a proper purpose; (b) in the best interests of the company [...]. ${ }^{41}$

When considering section 76(3)(b) on face value, it seems if the common law position of shareholder primacy has been retained, despite the concept of 'the company' (as metaphysical entity) always being contentious. ${ }^{42}$ When considering this section against the remainder of the 2008 Companies Act, it soon becomes clear that the philosophy of stakeholder protection in the Act is not clear. To provide a few instances: Section 5(1) of the Companies Act states that the Act must be interpreted in such a way that gives best effect to the purposes listed in section 7 . As indicated before, section $7(d)$ specifically provides that directors have to manage a company in such a manner that promotes both economic and social benefits. ${ }^{43}$ Section 1 , on the other hand, defines a profit company as '... a company incorporated for the purpose of financial gain for its shareholders.' The same principle is found in section 81(1)((d)(i)(bb), which provides for the winding-up of a solvent company ${ }^{44}$ in deadlock if its business cannot be conducted to the advantage of shareholders generally. Clearly, these sections focus on profit maximisation for shareholders, as opposed to benefiting all stakeholders. Thus, although it may be argued that the general philosophy of the Act, as stated above, is to take account of the interests of all the stakeholders, this philosophy is not applied consistently in the provisions that are more specific, which creates uncertainty.

\section{Emphasis added. \\ 42 See Percival $v$ Wright [1902] 2 Ch 421; Pergamon Press Ltd $v$ Maxwell [1970] 2 All ER 809 (Ch); Bell v Lever Brothers Ltd [1932] AC 161 (HL); SA Fabrics Ltd $v$ Millman NO 1972 (4) SA 592 (A); Minister of Water Affairs and Forestry $v$ Stilfontein Gold Mining Co Ltd 2006 (5) SA 333 (W). In some circumstances directors may become bound by special duties to members, creditors or others, e.g. a duty of disclosure or a duty not to give incorrect information: see eg Coleman $v$ Myers [1977] 2 NZLR; Brouze $v$ Wenneni Investments (20427/2014) [2015] ZASCA 142 (30 September 2015).}

43 It is doubtful that section 7(d) establishes a new, sui generis, duty on directors. It rather seems, against the background of the Policy Document, that section 7 (d) should also be interpreted to mean that directors must pay attention to the interests of stakeholders, but that it does not provide stakeholders with direct rights. Furthermore, if the legislator wanted to create a new duty applicable to directors it would have been done explicitly (maybe by listing it in section 76 with the other duties) and not by merely incorporating it into the 'purpose' provision. Also, in section 158(b)(i) it is held that if a provision in the Act, read in its context, can be reasonably construed as having more than one meaning the meaning that best promotes the purposes of the Act must be preferred by the courts. See also Joubert 186 , footnote 15 where he states that $s 7(d)$ is only one of the objectives. See, for example also s 7(b)(iii) on the promotion of enterprise efficiency'.

44 A solvent company is one that is commercially solvent, i.e. not commercially insolvent: Boschpoort Ondernemings (Pty) Ltd $v$ Absa Bank Ltd 20142 SA 518 (SCA) ([2014] JOL 31202 (SCA)) para 21. 
Be that as it may, stakeholders receive substantial protection in the Act: many of the provisions in section 7 are drafted in line with wider purposes than merely profit maximisation and the establishment of the social and ethics committee provides stakeholders with good protection as their interests cannot be ignored. King III, and now King IV, although self-regulatory, is also clearly in favour of the inclusive approach. Case law, as indicated, also shows a very direct move towards protecting stakeholders where necessary. ${ }^{45}$

The JSE Listings Requirements furthermore impose a duty to report on social, health, environmental and ethical performance, the efficiency of risk management and internal control, and to disclose the degree of compliance with the King Report on all listed companies. ${ }^{46}$ In addition to requiring listed companies to comply with the King Report, the JSE Limited also launched a Socially Responsible Investment Index (SRI Index) in May 2004. ${ }^{47}$ In terms of this Index the JSE developed criteria to measure the 'triple-bottom line' performance of the FTSE/JSE All Share Index. ${ }^{48}$ The SRI Index therefore offers companies a benchmark for structuring their environmental, social and governance programmes. The criteria measure how companies have integrated principles into existing frameworks of governance across three areas: policy and strategy, management and performance and reporting. ${ }^{49}$ The establishment of this Index is a good starting point, but the standard of measurement will always be controversial. The SRI Index was replaced

45 See here, very recently, the case of Mthimunye-Bakoro $v$ Petroleum Oil and Gas Corporation of South Africa (SOC) Limited [2015] JOL 33744 where corporate governance was defined as '.. the animating idea of which is to ensure net gains in wealth for shareholders, protect the legitimate concerns of other stakeholders and improve efficiency, organisational performance and resource allocation:

46 See Listings Requirement 3.84 dealing with corporate governance requirements and Potgieter and Another v Howie 20143 SA 336 (GP) in respect of enforcement. The JSE is one of the top 20 exchanges in the world in terms of market capitalisation. More than 400 companies are listed on the Main Board. South Africa is currently ranked 1st in the world in terms of regulation of securities exchanges and second for raising capital through the local equity market according to World Economic Forum's Global Competitiveness Survey for 2013-2014. Almost one fifth of the Main Board companies are dual listed. See: www.jse.co.za/capital/main-board.

47 For the SRI Index see: https://www.jse.co.za/About-Us/SRI/Criteria.aspx. The last annual review of the Index took place in 2014. The SRI Index will continue to be calculated until the end of 2015 , based on the results from the 2014 review. Going forward, assessment will take place as part of the collaboration with FTSE Russell. See: https://www.jse.co.za/services/marketdata/indices/socially-responsible-investment-index for the announcement.

48 See http://www.jse.co.za/sri/index.htm.

49 The following companies were the best performers of the SRI Index during 2014: Anglo American plc, Anglo American Platinum, Barloworld Medium, Illovo Sugar Limited, Lonmin plc, Netcare Limited, Royal Bafokeng Platinum, Standard Bank, Vodacom Group Ltd. See: https://www.jse.co.za/ content/JSEIndexConstituentsandWeightingsitems/2014SRIIndexConstitue ntsbestperformers.pdf. 
at the end of 2015 and the FTSE ESG ${ }^{50}$ Ratings are now used to select the constituents for the creation of the FTSE/JSE Responsible Investment (RI) Index. 51

\section{Conclusion}

The main objective of companies, at least from the viewpoint of the shareholders, remains the maximisation of profits for its shareholders. A failure by companies to meet the financial expectations of shareholders is often dealt with by instructions to sell their shares and the shareholders therefore 'vote with their feet'. 52 This being said; society also expects companies to be good corporate citizens ${ }^{53}$ and '[i]t is clear that it cannot be business as usual for SA companies going forward'. 54

It is submitted in this article that a committee such as the Social and Ethics Committee is a move to protect the interests of stakeholders in the context of company law in South Africa. ${ }^{55}$ However, the efficacy of this committee in achieving this will be evaluated hereafter.

50 The acronym for 'environmental, social and governance'.

51 JSE FTSE/JSE Responsible Investment Index Series (October 2015) 2 and www.jse.co.za, Products and Services - FTSE/JSE Responsible Investment Index Series and also Van der Ahee An Investigation of the Influence of ESG issues on the Decision Making of Institutional Investors in South Africa (MCom thesis 2012 University of Pretoria).

52 Joubert 183-185.

53 Joubert 185 refers to interesting statistics where he states that the aggregate market capitalisation of companies listed on the JSE (of more than $\$ 800$ billion) was more than twice the South African GDP in 2011.

54 Jennings 2015 The Journal of Corporate and Commercial Law \& Practice 80.

55 Locke 'Enhanced accountability' in Esser \& Havenga (eds) Corporate Governance Annual Review 2012 (2012) at 107 also states that 'The enhanced accountability requirement that best illustrates the prominence that the 2008 Companies Act places on the role of companies in greater society is the requirement to appoint a social and ethics committee'. 